Boletín de la Sociedad Geológica Mexicana

VOLUMEN 65, NÚM. 2, 2013, P. 299-305

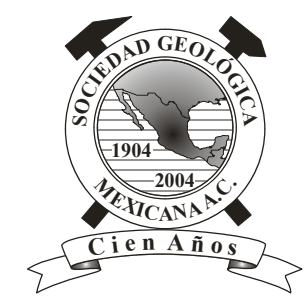

\title{
Cenomanocarcinus vanstraeleni Stenzel, 1945 (Crustacea, Decapoda, Brachyura, Cenomanocarcinidae) from the Late Cretaceous (Turonian) of Morocco
}

\author{
Alessandro Garassino ${ }^{1, *}$, Giovanni Pasini ${ }^{2}$, Héctor Porras-Múzquiz ${ }^{3}$, Francisco J. Vega ${ }^{4}$ \\ ${ }^{1}$ Museo di Storia Naturale, Sezione di Paleontologia, Corso Venezia 55, I-20121 Milano, Italia. \\ ${ }^{2}$ Via Alessandro Volta 16, I-22070 Appiano Gentile (Como), Italia. \\ ${ }^{3}$ Museo de Múzquiz A. C., Zaragoza 209, Múzquiz, Coahuila, 26340, Mexico. \\ ${ }^{4}$ Instituto de Geología, Universidad Nacional Autónoma de México, Ciudad Universitaria, Coyoacán, 04510 México, D.F., Mexico. \\ *alegarassino@gmail.com
}

\begin{abstract}
Cenomanocarcinus vanstraeleni Stenzel, 1945 (Cenomanocarcinidae Guinot, Vega and Van Bakel, 2008) is reported from the Late Cretaceous (Turonian) of Morocco. The discovery of Cenomanocarcinus vanstraeleni along the antique Northern Atlantic Moroccan coast may suggest a distribution of the genus from the Western Central Atlantic to the African coasts following two different directions. In addition, the morphological variation of C. vanstraeleni on multiple specimens from Cenomanian-Turonian localities of Colombia, Mexico, and United States is discussed.
\end{abstract}

Keywords: Crustacea, Decapoda, Brachyura, Late Cretaceous, Morocco.

Resumen

Se reporta Cenomanocarcinus vanstraeleni Stenzel, 1945 (Cenomanocarcinidae Guinot, Vega y Van Bakel, 2008) para el Cretácico tardio (Turoniano) de Marruecos. El descubrimiento de Cenomanocarcinus vanstraeleni a lo largo de la antigua costa marroqui del Altlántico Norte podría sugerir una distribución del género desde el Atlántico Centro-Occidental hasta las costas africanas, siguiendo

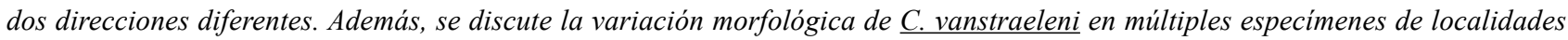
del Cenomaniano-Turoniano de Colombia, México, y Estados Unidos.

Palabras Clave: Crustacea, Decapoda, Brachyura, Cretácico Superior, Marruecos.

\section{Introduction and geological setting}

The studied specimen has been collected from an uncertain quarry in the eastern hinterland of the Tarfaya village, located into the southern part of the homonymous Tarfaya Basin developed on the western margin of the Moroccan South-Western Sahara, along the Atlantic coast. The Tarfaya Basin is a tectonically stable Mesozoic basin stretching $1000 \mathrm{~km}$ along the western margins of the Sahara Desert including a well-documented Upper Cretaceous succession (El Albani et al., 1999) in presence of high sedimentary rates of anoxic cyclic marine deposits (Keller et al., 2008) and fluctuating climatic conditions during the Cenomanian-Turonian (C-T) boundary (Tantawy, 2008). The C-T succession crops out along the basin, preserving a rich invertebrate fauna, mostly composed of Late Cretaceous 
(Turonian) cephalopods, which have been recently offered by local diggers onto the open international fossil market. Crustacean remains are very rare and only occasionally detected or, possibly, not collected by the local workers. The single specimen of $C$. vanstraeleni Stenzel, 1945 was discovered from a coarse carbonate level, associated with a well-preserved and partially silicified (usually the phragmocone) ammonite fauna pertaining to the Turonian ammonite succession (Kennedy and Wright, 1979), among which Kamerunoceras turoniense (d'Orbigny, 1950; Acanthoceratidae De Grossouvre, 1894) and the most common Mammites nodosoides (= var. afra Pervinquière; see Collignon, 1966; pl. 20, fig. 13;Acanthoceratidae De Grossouvre, 1894) have been recognized (F. Bacchia pers. comm., 2012). Kamerunoceras turoniense was reported from around the paleoprovince Afro-Atlantica (the Americas, Europe and Africa), ranging from the early to early mid-Turonian (Late Cretaceous) (Kennedy and Wright, 1979; Barroso-Barcenilla, 2007), whereas M. nodosoides is a worldwide exclusive species from the upper early Turonian (Late Cretaceous) (=Mammites nodosoides zone). Therefore, without more detailed geological and stratigraphic data, we confidentially ascribe the specimen to the Turonian (more possibly early Turonian; Late Cretaceous).

\section{Material}

The specimen, a complete carapace in dorsal view, is three-dimensionally preserved into a hard carbonatic matrix. It has been assigned to Cenomanocarcinus vanstraeleni Stenzel, 1945 (Cenomanocarcinidae Guinot, Vega and Van Bakel, 2008). The specimen is deposited in the Palaeontological Collection of the Museo di Storia Naturale di Milano (MSNM). For higher-level classification, we follow Van Bakel et al. (2012).

\subsection{Abbreviations}

lcxp: length of carapace; wcxp: width of carapace.

\section{Systematic Paleontology}

Infraorder Brachyura Latreille, 1802

Section Podotremata Guinot, 1977

Subsection Raninoidia De Haan, 1839

Superfamily Palaeocorystoidea Lörenthey in Lörenthey and Beurlen, 1929

Family Cenomanocarcinidae Guinot, Vega and Van Bakel, 2008

Genus Cenomanocarcinus Van Straelen, 1936

Type species: Cenomanocarcinus inflatus Van Straelen, 1936, by subsequent designation by Stenzel (1945: 447).
Included fossil species: Cenomanocarcinus beardi Schweitzer, Feldmann, Fam, Hessin, Hetrick, Nyborg and Ross, 2003; C. cantabricus Van Bakel, Guinot, Artal, Fraije and Jagt, 2012; C. dissimilis Collins, 2010; C. inflatus Van Straelen, 1936; C. multituberculatus (Joleaud and Hsu, 1935); C. oklahomensis (Rathbun, 1935); C. pierrensis (Rathbun, 1917); C. tenuicarinatus Collins, 2010; $C$. vanstraeleni Stenzel, 1945.

\section{Cenomanocarcinus vanstraeleni Stenzel, 1945}

Figures 1; 2.1-2.8; 3.1-3.6

Cenomanocarcinus vanstraeleni Stenzel, 1945: 447450, fig. 15, Pl. 44 (figs. 1-6).

Cenomanocarcinus vanstraeleni - Förster, 1968: 4. Finsley, 1989: 98, 99, pl. 78 (photos 307, 308). — Bishop et al., 1992: fig. 7c. — Vega et al., 2007: 412, 414, 417, 418, fig. 7.2-7.9, 8.1-8.11, 9.1-9.5. - Patarroyo and RojasBriceño, 2007: 92, 93, pl. 2 (fig. 1-4). — Guinot et al., 2008: 11, fig. 2, 3A-D, 3F, 4, 5. - Vega et al., 2010: 268-271, figs. 7, 8.1-8.5. - Schweitzer et al., 2010: 70. — Van Bakel et al., 2012: 54, 56, 57, fig. 18B, C, E.

Necrocarcinus vanstraeleni - Kues, 1980: 862-864, fig. 1 .

Necrocarcinus (Cenomanocarcinus) vanstraeleniToolson and Kues, 1996: 114, 115, fig. 1.5.

Ophthalmoplax spinosus Feldmann, Villamil and Kauffman, 1999: 96, fig. 3, 4.

Cenomanocarcinus sp. Guinot, Vega and Van Bakel, 2008: 694, fig. 3E.

Locality: Tarfaya Basin (Morocco).

Geological age: early Turonian (Late Cretaceous).

Material and measurements: one complete carapace (MSNM i27829 - lcxp: $57 \mathrm{~mm}$; wcxp: $41 \mathrm{~mm}$ ).

Description: Carapace medium sized for genus, subhexagonal in outline, wider than long; maximum width at epibranchial spine nearly at the middle length of the

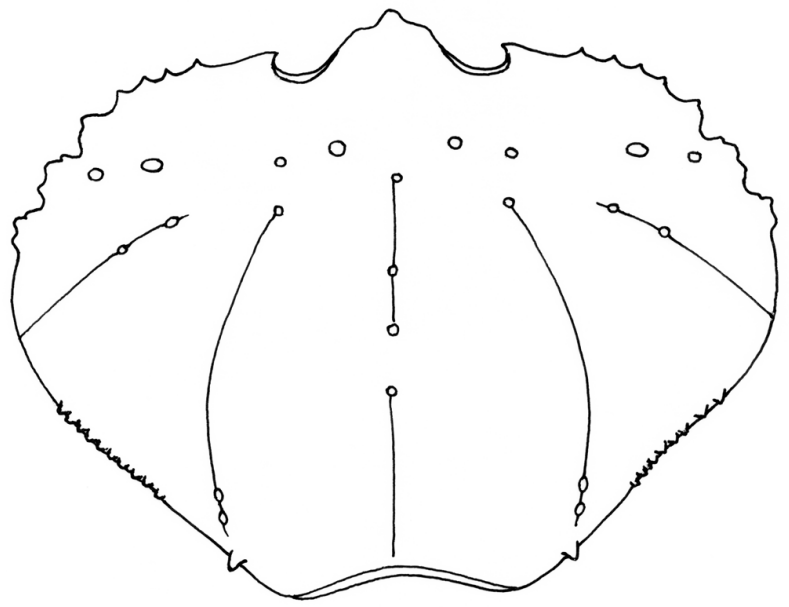

Figure 1. Cenomanocarcinus vanstraeleni Stenzel, 1945, reconstruction of carapace in dorsal view. 

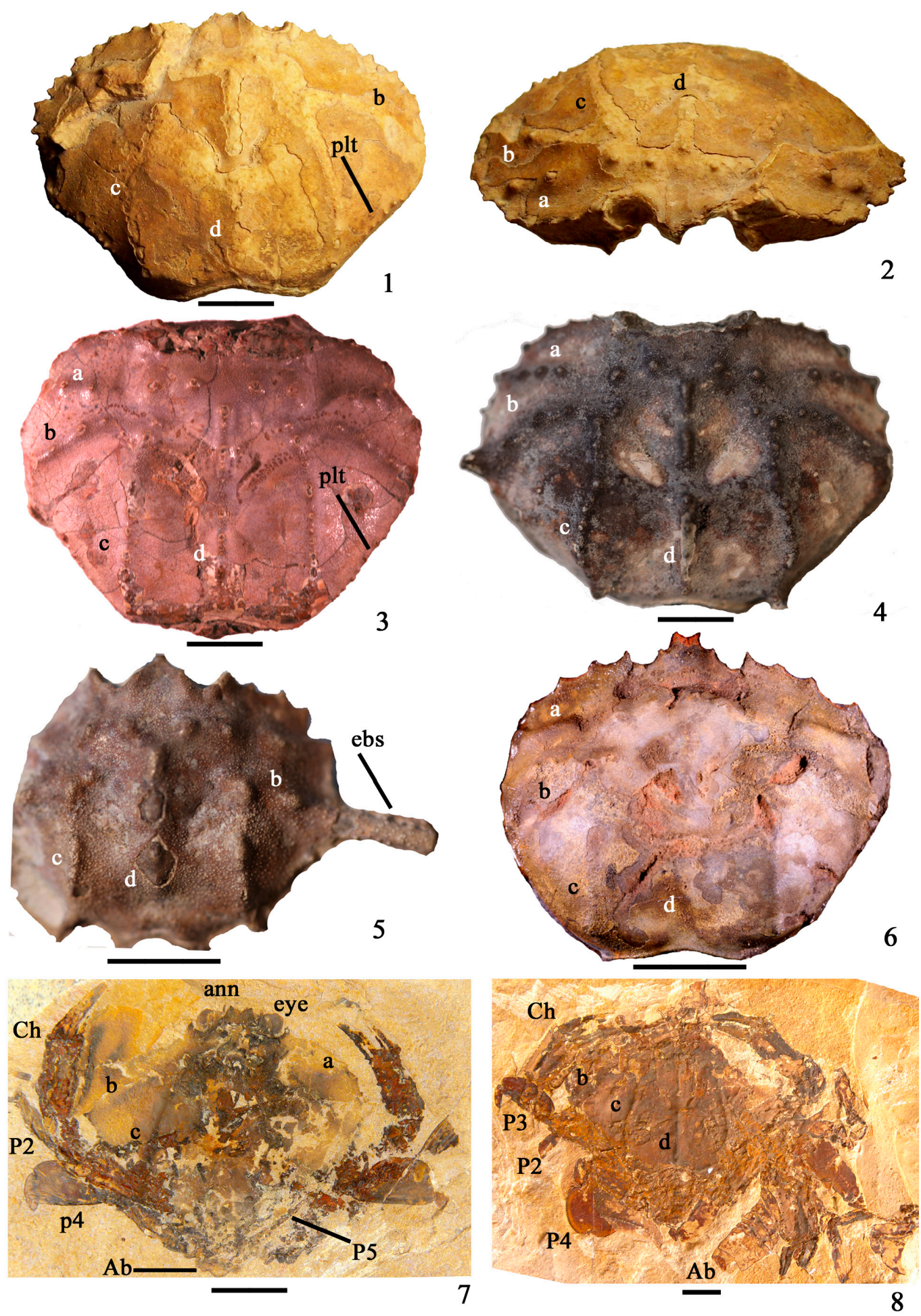

Figure 2. 1-8, Cenomanocarcinus vanstraeleni Stenzel, 1945. 1. Hypotype MSNM i27829, dorsal carapace, early Turonian, Tarfaya Basin (Morocco). 2. Frontal view, same specimen. 3. Hypotype IGM-6112 (Colección Nacional de Paleontología, UNAM), dorsal carapace, Cenomanian, Eagle Ford Group, Texas. 4. Specimen at the National Museum of Natural History, Smithsonian Institution, Accession number 2009822, dorsal carapace, Cenomanian, Woodbine Formation, Texas. 5. Specimen at the National Museum of Natural History, Smithsonian Institution, Accession number 2009820, dorsal carapace, Cenomanian, Woodbine Formation, Texas. 6. Hypotype INGEOMINAS-JCR-1 (Museo Geológico José Royo y Gómez, Servicio Geológico Colombiano, Bogotá, Colombia, dorsal carapace, Albian, Upper San Gil Formation, near Villa de Leiva, Department of Boyacá. 7. Hypotype MUZ-801 (Museo de Múzquiz, Múzquiz, Coahuila, Mexico), dorsal carapace, Turonian, Eagle Ford Group, Múzquiz Quarries, Coahuila, México. 8. Hypotype MUZ -701, dorsal carapace, Turonian, Eagle Ford Group, Múzquiz Quarries, Coahuila, México. Abbreviations and symbols: $a=$ hepatic ridge, $b=$ epibrachial ridge, $\mathrm{c}=$ metabranchial ridge, $\mathrm{d}=$ posteroaxial ridge; $\mathrm{ann}=$ antennulae; ebs = epibranchial spine; $\mathrm{plt}=$ posterolateral tubercles; $\mathrm{Ab}=\mathrm{abdomen} ; \mathrm{Ch}=\mathrm{cheliped} ;$ $\mathrm{P} 2-\mathrm{P} 5=$ second to fifth pereiopods. Scale bars $=1 \mathrm{~cm}$. 
carapace, posterior to the epibranchial spine; front advanced, downward-pointed, with one additional tooth at inner orbital corner upward-directed; deep rounded orbits, forwarddirected; long anterolateral margin, arched, with seven teeth (including epibranchial tooth): pointed, stout anterior four triangular teeth, slightly increasing in size posteriorly followed by three broad three-cuspidate teeth separated by deep concave indentations; epibranchial tooth incomplete; posterolateral margin longer, converging backward, sharp edged, with almost 7/8 small teeth unequal in size at level of metabranchial region, decreasing posteriorly and one small stronger tooth at the posterior corner at the end of the longitudinal ridge; posterior margin strongly concave axially, defined by fine ridge behind a narrow groove, nearly as wide as orbito-frontal margin; granulated longitudinal ridges, axially convex, originated by an epibranchial tubercle, and bearing two distinct teeth posteriorly; weakly vaulted dorsal carapace regions, defined by shallow grooves, with coarse, blunt tubercles; protogastric region with two small tubercles not aligned; hepatic region with two tubercles not aligned, similar in size; mesogastric region with two elongated tubercles; epibranchial region with strong tuberculated ridge, slightly downward-curved laterally, bearing almost two (maybe three) tubercles similar in size; relatively broad cardiac region, defined by almost one elongated tubercle, bounded by shallow lateral grooves; small intestinal region, slightly depressed; smooth mesobranchial and metabranchial regions; cervical groove weakly marked U sharped, even axially; branchiocardiac groove well defined at inner portion of epibranchial region; smooth dorsal carapace surface with very rare, sparse, small granules specially on the orbito-frontal and metabranchial regions.

Discussion. Curvature and armature of the anterolateral margin; the narrow orbito-frontal margin; the triangular three-spined rostrum; the division of coarse tubercles on the dorsal carapace; and the possession of three ridges on the posterior carapace all are diagnostic features of Cenomanocarcinus (Fig. 1, 2.1, 2.2). As reported by Van Bakel et al. (2012) nine species are assigned to this genus. Among these, C. vanstraeleni Stenzel, 1945, ranging from the upper Albian to lower Cenomanian of Europe and Americas, share some affinities with the specimen reported on herein, such as the general ornamentation and form of the ridges on the carapace, and specially the posterolateral margin with four small teeth that are at level with the metabranchial region (label plt on Fig. 2.1 and 2.3). Indeed, C. vanstraeleni is the only species known to date to possess small teeth along the posterolateral margin. Cenomanocarcinus dissimilis Collins, 2010, from the lower Cenomanian (Odukpani Formation, Calabar-Ikam road, SE Nigeria) could probably be assigned to C. vanstraeleni, based on the shape and ornamentation of the dorsal surface of the carapace; however, the comparison is difficult because of the poor preservation of the antero- and posterolateral margins of the Nigerian species.
The morphological variation of $C$. vanstraeleni can be documented on multiple specimens from CenomanianTuronian localities of the San Rafael Formation of Colombia and the Eagle Ford Group of Mexico and Texas (Vega et al., 2007; 2010; Patarroyo and Rojas-Briceño, 2007). It is interesting to note that $C$. vanstraeleni is probably the only brachyuran species preserved in the fossil record both as two-dimensional prints (e.g. Lagerstätten deposits of Mexico and Colombia, Fig. 2.7, 2.8, 3.1, 3.3, 3.5 and $3.2,3.4,3.6$, respectively) and as three-dimensional carapaces (Albian of Colombia and Cenomanian-Turonian of Texas, Figures 2.6 and 2.3-2.5, respectively). Mass mortality events are documented for the San Rafael and Eagle Ford Formations (Turonian) of Colombia and Mexico respectively, causing deposit and disarticulation of carapaces on the sea floor (Fig. 3.5, 3.6). This may have led to confusion in the identification of species. For example, Van Bakel et al. (2012: 54, fig. 17A-17D, 18F) illustrated specimens of $C$. beardi from the Cenomanian Woodbine Formation of Texas, based mainly on presence of a large epibranchial tooth and tubercles of branchial crests. Specimens from the Woodbine Formation show that feature (Fig. 2.5), but specimens from the same locality show typical features of C. vanstraeleni too (Fig. 2.4). This is also true for specimens of the Eagle Ford Formation of Texas (see fig. 7.9 in Vega et al., 2010 and photo 307 in Finsley, 1989). This would mean that there were either two species of Cenomanocarcinus sharing the same environment during Cenomanian-Turonian times, or that one species had broad carapace variability. If two species of the same genus were living together, then $C$. beardi originated in the Gulf Coast during Turonian times and then migrated to the Pacific by Santonian-Campanian times. The variability observed in carapaces of $C$. vanstraeleni from the CenomanianTuronian of Colombia, Mexico, and Texas, suggests that it is more probable that this species had a plastic response to different intrinsic and extrinsic factors, such as age, sexual dimorphism, oxygen, and depth, among others.

\section{Paleobigeography}

The discovery of Cenomanocarcinus vanstraeleni along the antique Northern Atlantic Moroccan coast may suggest a distribution of the genus from the Western Central Atlantic to the African coasts following two different directions; one southern directed to the Guinea Gulf, and a second toward the paleo-Tethys. These ways were possible due to the open communication among the basins during the late Cenomanian to the early Turonian (C-T transgression). The marine connection during early upper Albian to the early Cenomanian is substantially demonstrated by the ammonite fauna distribution (Kennedy and Cooper, 1975), whereas the evidence of an early Turonian distribution "is equivocal (due largely to an absence of early Turonian marine deposits in southern Africa), but such available 

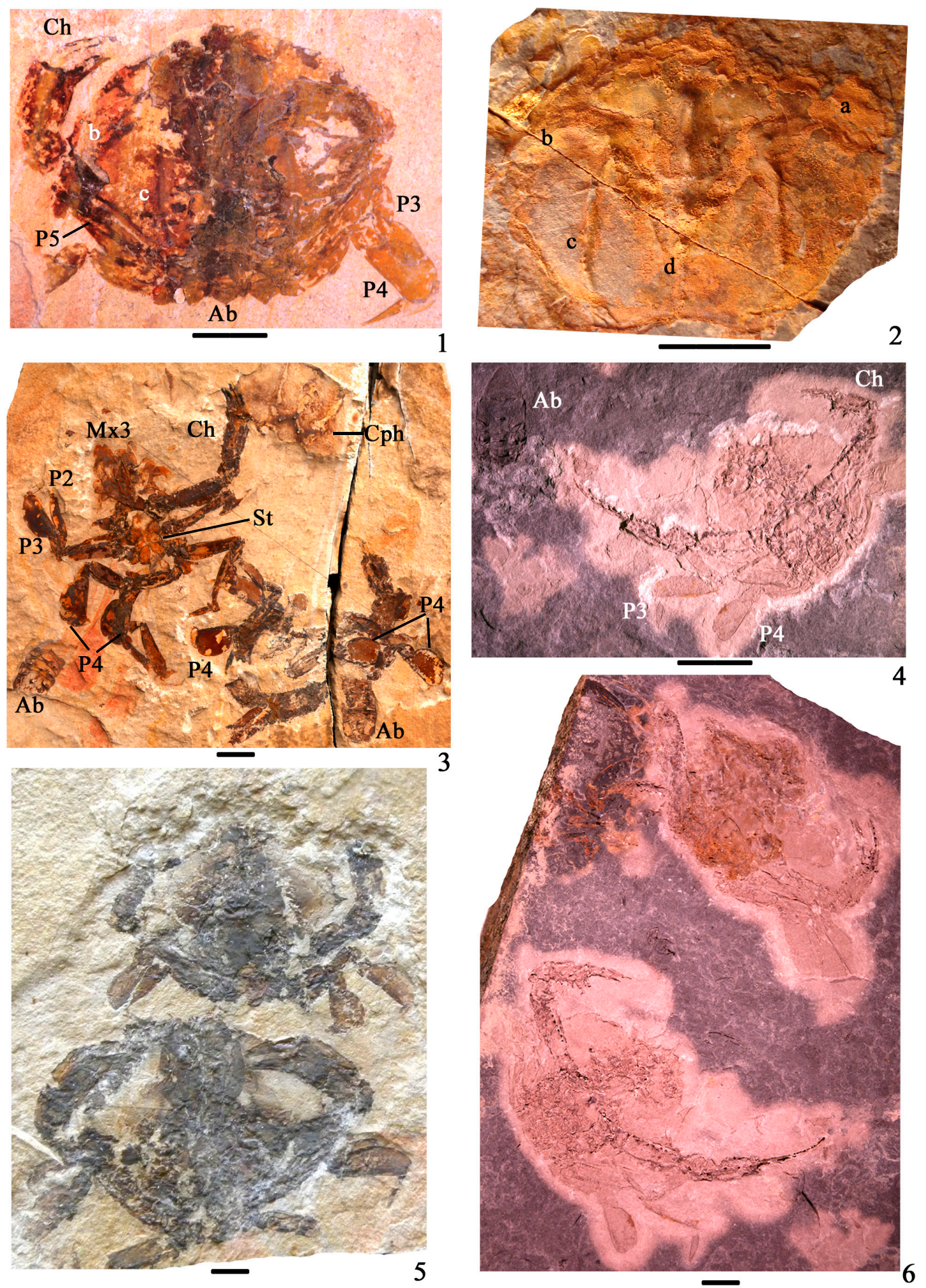

Figure 3. 1-6, Cenomanocarcinus vanstraeleni Stenzel, 1945. 1. Hypotype MUZ-802, dorsal view, Turonian, Eagle Ford Group, Múzquiz Quarries, Coahuila, Mexico. 2. Hypotype INGEOMINAS-NZ4b-03, dorsal view, lower Turonian, San Rafael Formation, Colombia. 3. Hypotype MUZ-708 B, remains of at least two specimens in mass mortality horizon, Turonian, Eagle Ford Group, Múzquiz Quarries, Coahuila, Mexico. 4. Hypotype UN-DGCR-014, ventral view, lower Turonian, San Rafael Formation, Colombia. 5. Hypotype MUZ-803, two specimens in mass mortality horizon, Turonian, Eagle Ford Group, Múzquiz Quarries, Coahuila, Mexico. 6. Hypotype UN-DG-CR-17, two specimens in mass mortality horizon, lower Turonian, San Rafael Formation, Colombia. Abbreviations and symbols: $\mathrm{a}=$ hepatic ridge, $\mathrm{b}=$ epibrachial ridge, $\mathrm{c}=$ metabranchial ridge, $\mathrm{d}=$ posteroaxial ridge; $\mathrm{Ab}=$ abdomen; $\mathrm{Ch}=$ cheliped; $\mathrm{Cph}=$ cephalothorax; $\mathrm{Mx} 3=$ third maxillipeds; $\mathrm{P} 2-\mathrm{P} 5=$ second to fifth pereiopods. Scale bars $=1 \mathrm{~cm}$. 
evidence also suggest continued connection" (Kennedy and Cooper, 1975). The wide distribution of C. vanstraeleni may be related to a semi-pelagic habit, as suggested by Vega et al. (2007). Cenomanocarcinus vanstraeleni occurs in mass mortality layers on Cenomanian-Turonian anoxic deposits of Colombia and NE Mexico. Several articulated and disarticulated carapaces have been found in the Turonian Múzquiz deposits of the Eagle Ford Group and the San Rafael Formation in Colombia (Fig. 3.5 and 3.6 , respectively), with estimated depths of 50-100 m (Stinnesbeck et al., 2005). The Múzquiz fauna includes only pelagic elements, with inoceramids (tolerant to considerable depths) as the only true benthic organisms. It seems possible that $C$. vanstraeleni was an active swimmer, as suggested by the extremely thin cuticle, disc-shaped carapace, flat articles of P3 and P4, big eyes and spiny appendages. No unequivocal proof for a swimming habit has been found yet, but mass mortality horizons with disarticulated carapaces might indicate that corpses were transported to the bottom, at an approximate depth of no less than $50 \mathrm{~m}$ (Stinnesbeck et al., 2005).

\section{Acknowledgments}

We wish to thank F. Bacchia, Trieste, for assisting in the determination of the associated cephalopod fauna and useful information on the Tarfaya outcrop; A. Biava, Rome (Italy), who donated the specimen to the Paleontological Collection of the Museo di Storia Naturale di Milano; A. Ossó-Morales, Tarragona (Catalunya) and T. Nyborg, Department of Earth and Biological Sciences, Loma Linda University, CA (USA), for careful review and criticism.

\section{References}

Barroso-Barcellina, F., 2007, Revision and New Data ot the Ammonite Family Acanthoceratidae De Grossouvre, 1894 from the Lower Turonian of the Iberian Trought, Spain: Palaeontographica Abteilung A, 280, 123-163.

Bishop, G.A., Brannen, N.A., Hill, L.E., Meyer, J.P., Pike, A.J., Sampson, C., 1992, The Britton Notopocorystes assemblage: an Eagle Ford decapods assemblage from the Cretaceous of north-central Texas, in Transactions of the $42^{\text {nd }}$ Annual Convention: Jackson, Missouri, U.S.A., Gulf Coast Association of Geological Societies, 413-424.

Collignon, M., 1966, Les Céphalopods crétacés du basin côtier de Tarfaya, in Notes et Mémoires du service Géologique du Maroc: Service Geologique du Maroc, 175, 1-78.

Collins, J.S.H., 2010, New species of crabs (Crustacea, Decapoda), one from the Middle Danian of Denmark, and three new species from the Upper Cretaceous of Nigeria: Bulletin of the Mizunami Fossil Museum, 36, 13-19.

De Haan, W., 1833-1850, Crustacea., in von Siebold, P.F., (ed.), Fauna Japonica sive Descriptio Animalium, quae in Itinere per Japoniam, Jussu et Auspiciis Superiorum, qui summum in India Batava Imperium Tenent, Suscepto, Annis 1823-1830 Collegit, Notis, Observationibus et Adumbrationibus Illustravit: i-xvii, i-xxxi, ix-xvi, 1-243, pls. A-J, L-Q, 1-55, circ. table 2. (J. Müller et Co., Lugduni Batavorum [=Leyden]).
El Albani, A., Kuhnt, W., Luderer, F., Herbin, J.P., Caron, M., 1999, The Oil and Gas habitats of the South Atlantic, in Cameron, N.R., Bate, R.H., Clure, V.S. (eds.), Palaeoenvironmental evolution of the late Cretaceous sequence in the Tarfaya Basin (Southwest of Morocco): London, England, Geological Society Special Publication, 153, 223-240.

Feldmann, R.M., Villamil, T., Kauffman, E.G., 1999, Decapod and stomatopod crustaceans from mass mortality lagerstatten Turonian (Cretaceous) of Colombia: Journal of Paleontology, 73, 91-101.

Finsley, C., 1989, A Field Guide to Fossils of Texas: Austin, Texas, U.S.A., Texas Monthly Press, $188 \mathrm{p}$.

Förster, R., 1968, Paranecrocarcinus libanoticus n. sp. und die Entwicklung der Calappidae in der Kreide: Mitteilungen aus der Bayerischen Staatssammlung für Paläontologie und historische Geologie, 8, 167-195.

Grossouvre, A. de, 1894, Recherches sur la craie supérieure, 2: Paleontologie. Les ammonites de la craie supérieure: Paris, France, Mémoirs du Service de la Carte géologique de la France, 264 p.

Guinot, D., 1977, Propositions pour une nouvelle classification des Crustacés Décapodes Brachyoures: Comptes rendus hebdomadaires des séances de l'Académie des sciences, 285, 1049-1052.

Guinot, D., Vega, F.J., Van Bakel, B.W.M., 2008, Cenomanocarcinidae n. fam., a new Cretaceous podotreme family (Crustacea, Decapoda, Brachyura, Raninoidia), with comments on related families: Geodiversitas, 30, 681-719.

Joleaud, L., Hsu, T., 1935, Crustacés décapodes du Crétacé de Tanout: Archives du Muséum national d'Histoire naturelle (Paris), 13, 100-110.

Keller, G., Adatte, T., Berner, Z., Chellai, E.H., Stueben, D., 2008, Oceanic events and biotic effects of the Cenomanian-Turonian anoxic event, Tarfaya Bassin, Morocco: Cretaceous Research, 29, 976-994.

Kennedy, W.J., Cooper, M., 1975, Cretaceous Ammonite distributions and the opening of South Atlantic: Journal of the Geological Society, 31, 283-288.

Kennedy, W.J., Wright, C.W., 1979, On Kamerunoceras Reyment, 1954 (Cretaceous: Ammnoidea): Journal of Paleontology, 53, 1165-1178.

Kues, B.S., 1980, A fossil crab from the Mancos Shale (Upper Cretaceous) of New Mexico: Journal of Paleontology, 54, 862-864.

Latreille, P.A., 1802-1803. Histoire naturelle, générale et particulière, des Crustacés et des Insectes, 3, 1-468.

Lörenthey, E., Beurlen, K., 1929, Die fossilen Decapoden der Länder der Ungarischen Krone: Geologica Hungarica (Palaeontologica), $3,1-421$.

Orbigny, A.d', 1950, Prodrome de Paléontologie stratigraphique universelle des animaux mollusques et rayonnés 2: Paris, France, Ed. Masson, $428 \mathrm{p}$.

Patarroyo, P., Rojas-Briceño, A., 2007, La sucesión y la fauna del Turoniano de la Formación San Rafael en Pesca y su comparación con la sección tipo en Samacá (Boyacá-Colombia-S.A.): Geología Colombiana, 32, 89-96.

Rathbun, M.J., 1917, New species of South Dakota Cretaceous crabs: Proceedings of the United States National Museum, 52, 385-391.

Rathbun, M.J., 1935, Fossil Crustacea of the Atlantic and Gulf Coastal Plain: Special Papers of the Geological Society of America, 2, $160 \mathrm{p}$.

Schweitzer, C.E., Feldmann, R.M., Fam, J.M., Hessin, W.A., Hetrick, S.W., Nyborg, T.G., Ross, R.L.M., 2003, Cretaceous and Eocene decapod crustaceans from southern Vancouver Island, British Columbia, Canada: Ottawa, Ontario, Canada, NRC Research Press, 66 p.

Schweitzer, C.E., Feldmann, R.M., Garassino, A., Karasawa, H., Schweigert, G., 2010, Systematic list of fossil decapod crustacean species: Crustaceana Monographs, 10, 1-222.

Stenzel, H.B., 1945, Decapod crustaceans from the Cretaceous of Texas: The University of Texas Publication, 4401, 401-476.

Stinnesbeck, W., Ifrim, C., Schmidt, H., Rindfleisch, A., Buchy, M.C., Frey, E., González, A.H., Vega, F.J., Cavin, L., Keller, H., Smith, K.T., 2005, A new lithographic limestone deposit in the Upper Cretaceous Austin Group at El Rosario, county of Múzquiz, Coahuila, northeastern Mexico: Revista Mexicana de Ciencias Geológicas, 22, 401-418. 
Tantawy, A.A., 2008, Calcareous nannofossils biostratigraphy and paleoecology of the Cenomanian-Turonian transition in the Tarfaya Basin, southern Morocco: Cretaceous Research, 29, 995-1007.

Toolson, E.K., Kues, B.S., 1996, Decapod crustaceans from the Semilla Sandstone Member, Mancos Shale (Upper Cretaceous), NorthCentral New Mexico: Journal of Paleontology, 70, 111-116.

Van Bakel, B.W.M., Guinot, D., Artal, P., Fraaije, R.H.B., Jagt, J.W.M., 2012, A revision of the Palaeocorystoidea and the phylogeny of raninoidian crabs (Crustacea, Decapoda, Brachyura, Podotremata): Zootaxa, 3215, 1-216.

Van Straelen, V., 1936, Crustacés décapodes nouveaux ou peu connus de l'époque Crétacique, Bulletin du Musée royal d'Histoire naturelle de Belgique, 12, 1-49.

Vega, F.J., Nyborg, T., Rojas-Briceño, A., Patarroyo, P., Luque, J., PorrasMúzquiz, H., Stinnesbeck, W., 2007, Upper Cretaceous Crustacea from Mexico and Colombia: similar faunas and evironments during Turonian times: Revista Mexicana de Ciencias Geológicas, 24, 403-422.
Vega, F.J., Nyborg, T., Kovalchuk, G., Etayo, F., Luque, J., Rojas-Briceño, A., Patarroyo, P., Porras-Múzquiz, H., Armstrong, A., Bermúdez, H., Garibay, L., 2010, On some Panamerican Cretaceous crabs (Decapoda: Raninoida): Boletín de la Sociedad Geológica Mexicana, $62,263-279$.

Manuscript received: July 20, 2012.

Corrected manuscript received: October 21, 2012.

Manuscript accepted: October 22, 2012. 